\title{
OBITUARIES
}

For the full versions of articles in this section see bmj.com

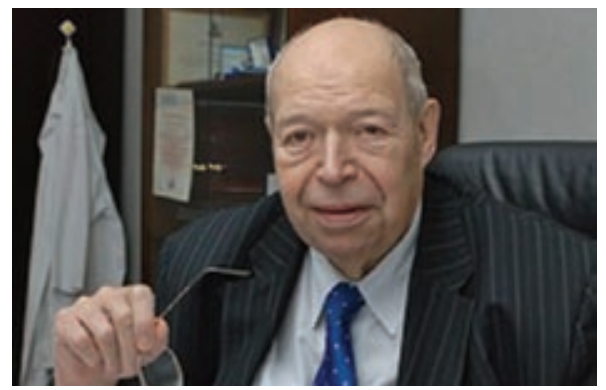

Valery Ivanovich Shumakov Outstanding heart surgeon who performed the first successful heart transplant in the USSR

Valery Ivanovich Shumakov was a leader in transplantation medicine in the former Soviet Union (USSR) and Russia. From 1974 until his death he directed the Research Institute for Organ and Tissue Transplantation (now the Research Institute of Transplantology and Artificial Organs). He performed the first successful heart transplantation in the USSR in 1987. For almost 20 years he was a coordinator of the Soviet-American collaboration on developing artificial hearts and mechanical circulation. His numerous inventions include a mitral valve prosthesis and several types of artificial heart.

Born in Moscow, the son of a construction engineer, he decided to be a surgeon at secondary school. In 1950 he became a student of the medical faculty of the First Moscow Medical Institute (now the Sechenov Moscow Medical Academy). There he met Gleb Solovyev (obituary, BMJ2004;329:1187), who was an aspirant (a postgraduate student preparing his kandidatskaya dissertation) at the chair of topographical anatomy and operative surgery and was obliged to teach undergraduates. In his book Memoirs of a Cardiac Surgeon (2002), Solovyev recalls that Shumakov, then a student just three years younger than him, asked the most difficult questions.

Solovyev recommended Shumakov to the aspirantura (a three year postgraduate programme) at the chair of topographical anatomy and operative surgery and introduced him to Boris Petrovsky (obituary, BMJ 2004;328:1381), a pioneer of Soviet heart surgery. Shumakov's kandidatskaya was on a new surgical correction of mitral valve prolapse, and Petrovsky performed about two dozen operations using Shumakov's technique.

In the early 1960s Petrovsky suggested that Shumakov develop a commercially available valve prosthesis. Together with engineers, Shumakov created a ball prosthesis of the mitral valve-Starr's ball valve prosthesis being the prototype-which was used in Soviet clinics for about two decades. His doctorskaya dissertation (similar to a habilitation thesis in Germany) on valve prostheses was published as a book with Petrovsky and Solovyev as coauthors in 1966.

The same year Shumakov was appointed head of the laboratory for artificial hearts and assisted circulation at the All-Union Research Institute for Clinical and Experimental Surgery directed by Petrovsky (now the Petrovsky Russian Scientific Centre for Surgery). In 1965 Petrovsky performed the first successful kidney transplantation from a living related donor in the Soviet Union. In 1971 Shumakov became a state prize laureate, together with Petrovsky and Solovyev, for kidney transplantation.

In 1969 Petrovsky established the Research Institute for Organ and Tissue Transplantation and appointed Solovyev as director. However, he did not let Shumakov join Solovyev, instead making him head of the department of transplantology and artificial organs at the All-Union Research Institute for Clinical and Experimental Surgery. Shumakov became the first in Europe to use intra-aortic balloon counterpulsation, in 1969.

In 1974 Shumakov became director of the Research Institute for Organ and Tissue Transplantation. By the late 1970s he had transplanted about 350 kidneys and had the greatest experience in this field in the USSR and Europe. He developed techniques of arterial anastomosis for multiple renal arteries, repeat kidney transplantation, and modified vesicoureteral anastomosis. He also studied acute and chronic rejection of renal transplants, management of patients after transplantation, and problems of haemodialysis. To prolong the viability of isolated donor kidneys he developed a special solution which bears his name.

In the early 1980s Shumakov established a laboratory of biomaterials to study haemocompatible polymers used in artificial organs. Several models of artificial heart and artificial ventricle were designed and tested in calves. He viewed implantation of an artificial heart as a "bridge" to heart transplantation.

According to the 1977 decree of the ministry of health, organ procurement was allowed only after the biological death of a donor. It took 10 years for the ministry to accept death on the basis of brain death. By then Shumakov had convinced the authorities to allow him to perform heart transplantations. His attempt in April 1987 was a success, the patient living for nine years.

A federal law in 1992 allowed transplantation on the basis of the presumed consent of brain dead patients to become potential donors. Shumakov did around 120 heart transplantations over 20 years, and his motto was "Not a day without an operation."

He was awarded numerous decorations and became a member of the Russian Academy of Sciences and the Russian Academy of Medical Sciences; a hero of Socialist Labour; a member of many international societies (including the Transplantation Society, the Society of Thoracic Surgeons, the International Society for Heart and Lung Transplantation, the International Federation for Artificial Organs); an honorary member of the French Society of Transplantologists and Czechoslovak Society of Surgeons; coeditor of Artificial Organs, and a member of the editorial board of Dialysis. He became an honorary citizen of Moscowthe second surgeon to receive the title, the first being Nikolai Pirogov in 1881. A star was named after him in the constellation Scorpio. He was a gourmet.

In 1962 he joined the Communist party-an absolute condition for an administrative and academic career in the USSR-but by the end of his life he had turned to religion and opened an Orthodox church in his institute.

He suffered from neglected acquired heart disease and died after heart surgery. He is survived by his wife, Natalya Mikhailovna Shumakova (née Kalitievskaya), a retired anaesthesiologist; his daughter, Olga, an art critic at the Tretyakov gallery; and his son, Dmitry, a professor of cardiac surgery at his father's institution; and four grandchildren.

\section{Boleslav Lichterman}

Valery Ivanovich Shumakov, professor of

surgery and director of the Research Institute of

Transplantology and Artificial Organs, Moscow (b

1931; q Moscow 1956; MD), died from heart failure on 27 January 2008.

OBITUARIES continue on p 779 


\section{Bruce Eton}

Former consultant obstetrician and gynaecologist Hastings Hospitals Group (b 1914; q Manchester 1943; MBE, FRCOG, MD), d 28 October 2007. Born Bruno Einhorn in Berlin, Bruce Eton left Germany in 1933, when the Nazis came to power, and came to England via Switzerland and Italy, where local legislation prevented him qualifying. With the help of the Church Stretton Refugee Committee he was admitted to Manchester Medical School. After brief internment in 1940 and service in the Pioneer Corps, he finally qualified in 1943, joining the Royal Army Medical Corps in 1944. The War Office advised he changed his name before serving in mainland Europe. On demobilisation in 1946 Bruce trained as an obstetrician in Bromley, becoming senior registrar at Addenbrooke's Hospital, Cambridge, in 1952 and then consultant in Hastings in 1961 until he retired in 1979. He leaves a wife, Ilse; two children; and three grandchildren. Rachel Ellis

\section{Heinz Fuld}

Former consultant physician Sefton and Newsham General Hospitals, Liverpool (b 1908; q Berlin 1930; MD, FRCP Ed), d 21 January 2008. Heinz Fuld studied medicine in Germany, gaining his MD in 1931 on agranulocytosis. He did research in Freiburg with Hans Krebs, following him to the United Kingdom in 1933 because of Nazi oppression. Having obtained his MRCP, Heinz entered general practice in south Liverpool until he was appointed consultant physician. A major in the Royal Army Medical Corps during the second world war, he was the first British doctor to enter Belsen on its liberation. After demobilisation, he was one of the first to describe macrocytosis resulting from dietary folate deficiency. After retiring from the NHS, he had a thriving private practice in Rodney Street, Liverpool. He leaves a third wife, Pat; their son; a daughter by his first marriage; a stepdaughter; and four grandchildren.

Chris Evans

\section{Peter David Graham}

General practitioner, Ross-shire (b 1958; q Aberdeen 1984; FRCGP), d 25 October 2007.

After passing part 1 of the FRCS in Aberdeen, Peter David Graham joined his father Robin in the Tain and Fearn practice in 1986 . He was a resourceful, energetic, and valuable colleague, with a unique sense of dress and of humour who knew his patients well. He soon developed training in the practice and became a notable college examiner. Outside medicine his main passion was field sports, of which he had unparalleled local knowledge and experience. He was always enthusiastic and generous with his time spent encouraging people in both sport and medicine. He leaves a wife, Christine, and one son.

\section{Sandy Gordon}

\section{David William Hill}

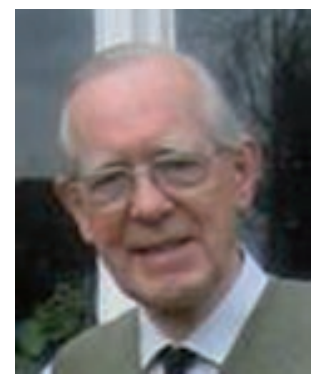

Former research professor in ophthalmology Royal College of Surgeons and consultant ophthalmologist Moorfields Eye Hospital (b 1927; q St Bartholomew's, London 1948; DO, FRCOphth), died 5 February 2008 after a stroke in 2006. After house jobs and national service in Austria, David William Hill pursued a career in ophthalmology. He became research professor in ophthalmology at the Royal College of Surgeons in 1967. His research covered retinal circulation and diabetic retinopathy and he continued his clinical work as a consultant at Moorfields Eye Hospital with an interest in cataract surgery. He examined for the Royal College of Surgeons and worked with the Royal National Institute for the Blind. He leaves a wife, Jean; three children; and eight grandchildren.

Rob Hill

\section{Paul Arthur Hooper}

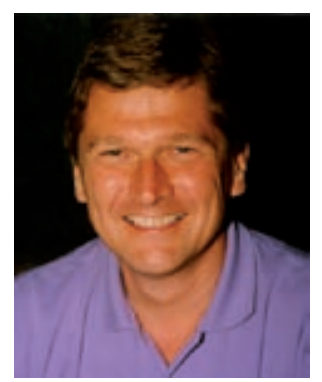

Executive vice president of Eisai Europe (b 1952; q Royal Dental Hospital, London 1976; BDS, FDS, MB BS), d 29 January 2008.

Having qualified in dentistry, Paul Arthur Hooper studied medicine with a view to a career in oral surgery. After a year as a senior house officer in ear, nose, and throat surgery he became disenchanted with the NHS and joined Roche as a medical adviser. In 1996 he spent a few months in the Medicine Control Agency before joining Eisai and shortly after joining became general manager of Eisai UK. Paul ran six marathons, raising considerable sums of money for charity. He leaves a wife, Nina; and two children, Jamie and Kathryn. Stuart Sanders

\section{Ghulam Hussain}

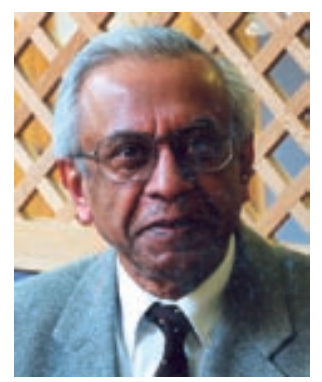

Former consultant radiologist South Buckinghamshire (b 1940; q Multan 1965; FRCR) died from complications of motor neurone disease on 15 August 2007.

After qualifying in Pakistan, Ghulam Hussain trained in radiology in the UK before becoming a consultant radiologist for Wycombe and Amersham hospitals in 1975. Ghulam almost single handedly laid the foundations of a modern department, and throughout his career he mastered all new modalities and was a major influence in setting up services in ultrasound, computed tomography, and magnetic resonance imaging. He was a founder member of the charity Scannappeal, which raised money to buy and run radiology equipment. He is survived by a wife, Lynden, and two sons.

Carolyn Charlesworth, Pam Kemp

\section{Hanuš Weisl}

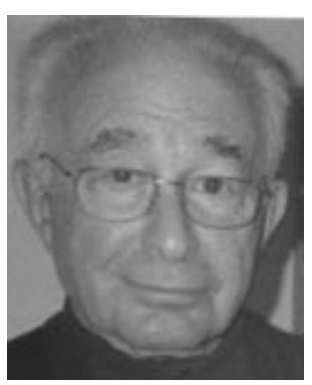

Former consultant orthopaedic and trauma surgeon South Glamorgan Area Health Authority (b 1925; q Manchester 1948; MD, FRCS, MChOrth), died from cerebral haemorrhage after a fall at home on 17 July 2007.

Hanuš Weisl escaped from Prague to Britain as part of Kindertransport in June 1939 on the last train before the borders were closed. On qualifying, he became a British citizen and started his first post as a house officer in Manchester Royal Infirmary at the inception of the NHS. Early in his career he became interested in orthopaedics, particularly the management of childhood deformities. He trained as a senior registrar at the Prince of Wales Hospital, Rhydlafar, near Cardiff, for three years and became consultant in Bolton in 1963, returning to Cardiff as a consultant with a specialist in club feet in 1969. Predeceased by his wife, Reba, in 1997, he leaves a daughter and a granddaughter.

J A Fairclough

ADVICE
We will be pleased to receive
obituary notices of around 250
words. In most cases we will be able
to publish only about 100 words in
the printed journal, but we can run a
fuller version on our website. We will
take responsibility for shortening.
We do not send proofs. Please give
a contact telephone number and,
where possible, supply the obituary
by email to obituaries@bmj.com

